\title{
THE ROLE OF THE ARAB HERITAGE IN ENHANCING THE BEAUTY OF THE EXHIBITION HALL OF THE MUSEUM OF NATURAL HISTORY OF IRAQ
}

\author{
Mahmmoud H. Abdul - Rahman Hussein \\ DOI: $10.37648 /$ ijrssh.v10i03.009 \\ Received: 25 ${ }^{\text {th }}$ May, 2020; Accepted:18 $8^{\text {th }}$ June, 2020; Published: $30^{\text {th }}$ June,2020
}

\section{ABSTRACT}

This research aims to show the role of Arab heritage in enhancing the beauty of the exhibition hall of the Iraqi Natural History Museum. The research included studies on the roots, origins and development of Arab heritage and its most important elements and the most important Iraqi painters who dealt with them in their artistic achievements, including (pioneer artist Ayath Abdul Rahman Al-Douri and pioneer artist Salam Jabbar Jiyad). Then how to employ the Arab heritage in the exhibition hall and what are the heritage items that were employed in the museum exhibit hall. Finally, the study reached several results, the most important of which were the vocabulary and elements of Arab heritage were employed in the museum's exhibition hall, such as the Arabian Palm, its parts and materials made from the palm, such as dishes, baskets, carpets, and decorative tools. Special cabinets are assigned to them in the museum's exhibition hall.

Key words: heritage, Arab, beauty, hall, museum, natural history.

\section{AN INTRODUCTION}

Heritage is a social achievement that belongs to the past in its various forms, be it scientific, literary, philosophical or artistic, and all forms of cultural expression, tangible and intangible, are included. This human heritage constitutes for every nation a root and a memory that contains the components of its historical awareness. He thus formulates his personality, conscience, and identity. Just as no individual can deny his past, his first components, environmental and hereditary, as well as no other people can deny his heritage and transcend his spiritual and intellectual structure, this authentic human heritage is an important part of our culture that must be preserved by collecting, codifying and analyzing it. And publish it. This heritage includes many elements, including customs, traditions, beliefs, games, crafts, proverbs, poetry, literature, and all forms of human creativity. There are many definitions of heritage language and convention by the scholars who specialize in it and their different approaches, so heritage has become many definitions. It is said, for example: cultural heritage, architectural heritage and natural heritage, as it is said folk heritage, Arab heritage, Islamic heritage and English heritage, and it is said: cultural heritage, cultural resources or cultural property. However, the concept of heritage is not complete without being associated with the concept of preservation and revival, and it is not a heritage unless it is felt and inherited by the legacy of the need to recognize it, reveal it, protect it and revive it and benefit from its inherent strength that emerges and develops 
according to their awareness of their heritage and their keenness to own and achieve self through continuing creativity in it and bearing Responsibility to pass it on to the generations that follow. In this study, the role of the Arab heritage to enhance beauty is set in the exhibition hall of the Iraqi Natural History Museum, hence the research problem that enables the researcher to formulate in the form of questions as follows:
A. What is heritage?
B. What is the concept of Arab heritage?
C. Where do its aesthetic features stand out?
D. Who are the most prominent modern and contemporary Iraqi artists who have paid attention to Arab heritage?
E. Does he have a role in enhancing beauty in the museum's exhibition hall?
F. What is the evidence for this?

The importance of this study lies in filling the research deficiency by highlighting the role of Arab heritage in enhancing beauty in the exhibition hall of the Iraqi Natural History Museum. As for its aim, it is to reveal the role that Arab heritage plays in enhancing beauty in the exhibition hall of the Iraqi Natural History Museum. search limits:

a) Time limits: 1996-2020.

b) Spatial limits: The Iraqi Natural History Museum exhibits hall.

c) Objective limits: The role of the Arab heritage in enhancing beauty in the exhibition hall of the Iraqi Natural History Museum.

\section{DEFINING TERMS:}

The meaning of heritage in language: inheritance, inheritance, inheritance, and heritage are all in one meaning, and the meaning of heritage: "What a man leaves for his heirs" (Ibn Manzur, 1990, V 2, p. 199) The word is launched, and it is reported according to the description that follows, so we say for example: heritage Islamic, Arab heritage, and human heritage (Al-Omari,
$1405 \mathrm{AH}$, p. 26), and the significance of heritage has expanded; It is not only an Arab Islamic heritage, but has become a human heritage, in some respects: the modern poet deals with this heritage from different angles (Abbas, 1992, p. 117). And in the terminology: "What we inherited from our fathers from the doctrine, culture, values, literature, arts, industries and other moral and material achievements, as well as includes the divine revelation (the Qur'an and the Sunnah of the Prophet), which we inherited from our ancestors" (Al-Omari, op. cit,).

There is natural, physical, physical, or geographical heritage, and includes the land and surface in its many forms of fertility, desertification, mountains, hills, hills, valleys, plains, rivers, seas, oceans, lakes, and swamps. All of them are factors that are related to each other and influenced by man and influenced by him (Badawi, 1986, p. 136).

As for the human heritage, it extends to all types of heritage, regardless of habitat. Because it relates to the individual and group. The human heritage represents "the accumulated traditions, customs, experiences, experiences, arts and sciences during the times of a people from the peoples", and it is "an essential part of its strength: social, human, political, historical, and moral, and this documents its relations with past generations. That worked on creating and enriching it (Jabbour, 1979, pp. 63-64).

Some specialists believe that there are six sources from which the poet and contemporary artist derive the topics of his works, namely:

1. Religious heritage.

2. Historical heritage.

3. Literary Heritage (Zayed, 1978, pp. 93 and beyond).

As for the definition of heritage, it is procedural: it is a social achievement that belongs to the past in its various forms, whether it is scientific, literary, philosophical or artistic, and includes all forms of cultural expression material and non-material.

\section{THE CONCEPT OF HERITAGE}

Despite knowing the meaning of heritage in language and terminology, as it appeared to the researcher that he has concepts that are not complete without being associated with the concepts of revival and preservation, and he thus does not carry the meaning of heritage unless it is felt by those who inherited it by urgency in identifying his concept and revealing, investigating, reviving, preserving, and benefiting greatly from his inherent strength His knowledge treasures that appear 
and develop as much as their awareness and interest in their heritage and the keen interest in them to own and achieve their own self through their communication with creativity in it and bearing the responsibilities of transferring it to their generations after them. Thus, the heritage of any society is divided into:

A) Physical heritage: such as archaeological dwellings and discoveries resulting from excavations, and the valuables contained in various museums that represent their eras, to strive to preserve their cultural, cultural heritage and the important ways to ensure its development. An example of this is from the Paleolithic period, when the artist immortalized drawings that resisted time to tell us about the cruel issue of living in that period (Cering, 1992, p. 500). Then man was able to play down the causes of his life and stability by subjecting the laws of nature to him and settling in buildings that denote nothing but the wisdom of his mind and his desperate insistence for his survival and control of his life however he wanted, and the evidence of Ibn Al-Rafidayn and Ibn Al-Nile to support the researcher in this fact so let the beholder look at his legacy that is almost Be eternal. After that, in his successive eras and in many parts of our earthly world, man continued to do so, wherever a form of his legacy came from these ancient buildings, and they constitute a heritage. Such as :

Constant effects, such as the remains of historical cities, religious buildings, architectural monuments, military fortifications, water and agricultural installations, tombs, and the like (that civilization is conditioned by a range of factors, the first being geological factors, the second geographical, then economic factors.( Durant, 2001, p. 3. Ismail, 1993, p. 15. Gold, 1996, p. 15). These monuments are considered compounds of human heritage or human culture, as the two terms coincide with heritage and culture, and that artistic, creative and intellectual activity in contemporary life is inspired, in its entirety, by heritage, and if one considers the synonym of the term culture and heritage in general, and in that the heritage is An expression of cultural continuity with a wide range in space and time. Archeology, architecture and the heritage of folk society(Figure1) have important gains among the components of the heritage itself, so it is not possible to limit the discussion on heritage without them, as these monuments are without a doubt a material aspect of it. They are

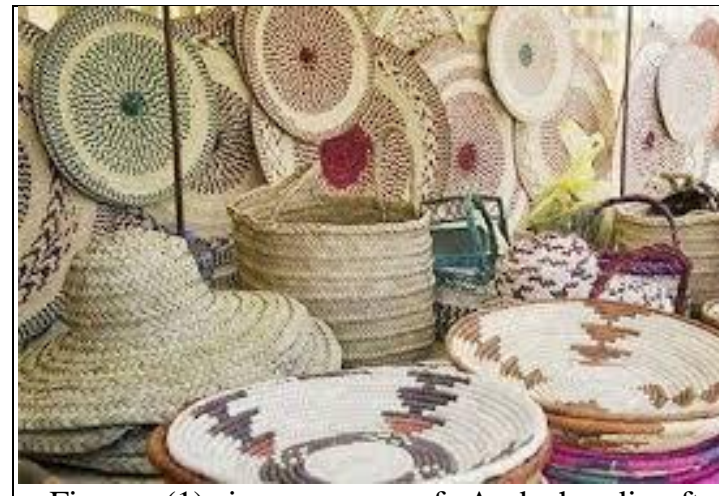

Figure (1) is a group of Arab handicrafts inherited from ancient times to today, which is a collection of baskets, dishes, bags and headgear, all made of palm leaves and some plant fibers

(straw). evidence of man's eternal conflicts with his surroundings and environment. And those relics are his cultural heritage, which embodied his human past in all its aspects. Undoubtedly, it occupies the first important position of historical sources, being concrete, visual and material images that man left for us through its different eras. Archeology is the science that studies the past. And to address extinct sections, it is a young science that arose in the middle of the twentieth century and caused a major coup with the knowledge of man's history and development in the discovery of different ancient civilizations and civilizations and changed the views of historians of civilizations of all kinds about the origins of human life and its roots (Baqer, $1400 \mathrm{AH} / 1980 \mathrm{AD}$, p. 10. Mola, 1998, p. 335 ).

B) Intellectual heritage: It is the things presented by writers, scholars, thinkers and politicians who were witnesses of their ages. As the stories of the apostles, prophets, and ancient ancient nations mentioned in the Bible (Bible, 1991, 44-46). And in it is that Isa Ibn Maryam (peace be upon him) was urging his disciples to study the legacy of the previous nations and follow their news. Likewise, his disciples taught people: "Go and make disciples of all nations." (Matthew Gospel: 19) Natural knowledge and various sciences such as early sciences and Arab-Islamic heritage in all natural sciences. These first sciences can be determined historically since Sumerian thought, the first founder of the systems of human history, according to the opinion of its specialists. The same is true in plastic and literary arts and the like. 
C) social heritage. This relates to the psychological and psychological life of the individual and society, such as the behavioral rules, frequent proverbs, traditions and customs that prevailed in the society, and they formed a long-term, coherent ethical building that affected the members of society. Accordingly, heritage is the cultural form that reflects the human characteristics and the basic phenomenon that is not necessary for human existence. These human achievements are inherited by virtue of the diversity of their social and environmental framework and the multiplicity of the task in action and interaction over the days (Figure 2).

So there is a difference in the conditions of the generations, without a doubt, depending on their gift of money, because their meetings are to cooperate in collecting that money and starting with it necessary and simple before the luxuries or needs (Ibn Khaldoun, (n.d), p. 110). That is why it should not confer upon it the character of divinity or the absolute quality of truth. As for the eternal and eternal data, such as the doctrine of faith, which is directed to all people in a place and time without privacy, the Bible, as well as the Holy Qur'an and the Sunnah of the Prophet are sacred, contrary to the achievements and diligence that they are made by human beings. Its formation as innovative images of interaction and integration in life and society and represents the heritage that deserves attention and respect is all and should be seen objectively in the framework of the human creative process in a perpetual movement that runs like the waters of rivers and streams and is renewed in a short moment of time. In this sense, concepts of

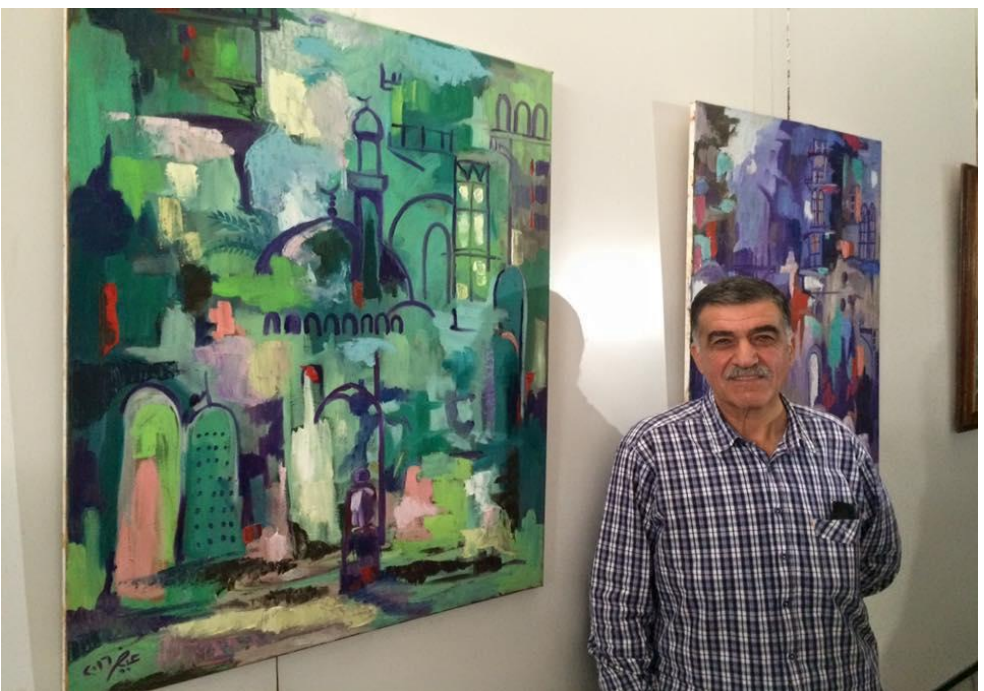

Figure 2: The great Iraqi artist Ayath Abdul Rahman Al-Douri. Specialized in Arab and Islamic heritage and arts. The artist stands among his works that were presented in the annual professors exhibition (2016) at the hall of the Faculty of Fine Arts / University of Baghdad. (The title of these works is: Alley Baghdadi (the inherited Baghdadi Heritage), the size of the work is $70 \times 80 \mathrm{~cm}$, oil on canvas). heritage can be conceived at the Arab and Islamic level by not contradicting any of the perceptions that come at the level that is local. The complete inclusiveness of the heritage of Arabs and Muslims is committed to undoubtedly preserving the cultural and cultural heritage of Arabs and Muslims and the ways to develop it as a social necessity for the situation of any Arab individual and the circumstances of any Islamic house (Al-Khaffaf, 1420 AH / 2000AD, pp. 7-8).

Arab society in the pre-Islamic era, which had been living since ancient times in the Arabian Peninsula, based on traditions, ideals and values that control its behaviors and regulate the relationships of its components with each other as it had an oral heritage and another written blogger that is in poetry and myth (Armstrong, 1429 AH / 2008 AD, p. 8). It is certain that the artist or the poet will have a very important impact in investing in the element of imagination that combines legend and poetry. The creation of the poem, which is closely related to mythological material, is closely related to a world similar to what is legendary, depending on the imagination of that poet or artist (Al-Naimi, 2005, p. 10). Its purposes were limited to spelling, praise, and lamentation, and highlighting eloquence and eloquence. This makes Islam to maintain old Arab values and rehabilitate pre-Islamic Arab heritage and purify it from extraneous impurities that do not fit with the teachings of Islam. The prolonged cultural activity associated with the rise of the new Islamic religion led to the extraction of previously unknown topics, which they denied curiosity and ambiguity and established many unfamiliar knowledge. As it appeared, it appeared between the beginning of Islam and the establishment of the mother Islamic state in the Levant, and the subsequent conquests, the breadth of the Islamic religion, and the mixing of the Arabs with the regions whose shadow came from other races. A color of new knowledge of linguistics brightened like (the triangles of Qatrab), and it was called so because it combines all three words into one group. The meaning of one changes according to its movements. It means semantic linguistic study of words that agree in the morphological structure of the arrangement of letters and differ in their 


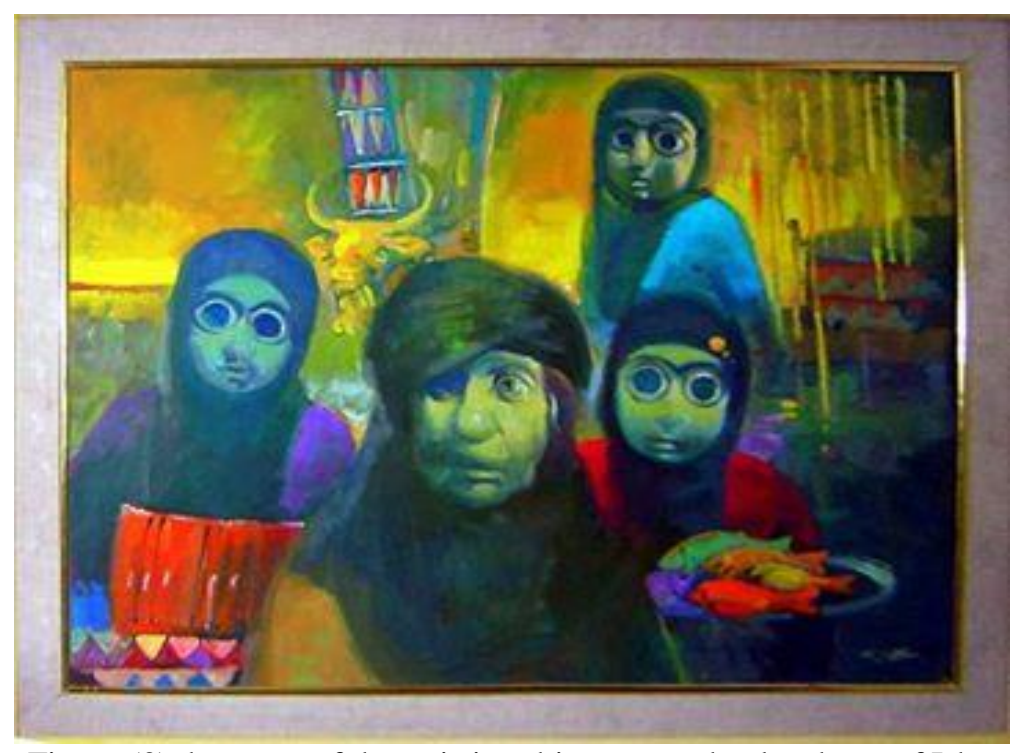

Figure (3) the name of the artistic achievement, the daughters of Ishtar (2007) by the pioneer artist, the giant of modern and contemporary Iraqi art (Salam Jabbar Jiyad). This heritage achievement represents the profound eternal relationship between the ancient and Islamic Iraqi heritage and modern. movements. The book for Sepoy and the full book for the file. In it, Muslims retained some of the pre-Islamic rituals, such as the sanctification of the Black Stone and the ancient religions of the East, such as Hajj, the torment of the grave, and circumcision, and using them to employ and synthesize a unified social discourse and build a new ideological thought related to Islam (Al-Sharafi, 2008, p. 26).

From this, the archaeological material overlaps with the original or authentic heritage, and in that the folklore included wide groups of folklore and fossils created by society in all its categories and spectrums with the extension of the country and what emerged from the traditions, customs, pictures, patterns and cultural methods, especially material and intellectual especially over the ages. Interacting with the environment, the ocean, and the universe, such as the local language, different dialects, many biographies, epics, tales, proverbs, and sayings. The same applies to various arts such as ornaments and crafts, such as architectural art, fashion and industries, which expressed the collective feeling, mutual interactions, interventions and relations with other cultures that are frequent throughout the ages and up to the present (Figure 3). Thus, the concept of the nation's heritage is its remaining balance, fixed ammunition and savings that reflect its progress in all civilizational and cultural fields (Diab, 1993, p. 9).

\section{ORIGINATION OF THE NATURAL HISTORY MUSEUM}

Museums were established since ancient times in conjunction with the emergence of the first person, where he wanted to preserve what he possesses his cherished holdings in private places, expressing his first intellectual concepts that became clear in the Neolithic period (Muhammad Ali, 1977, p. 28) in the small village of Jarmo, southeast of the city Kirkuk about 6750 BC. M. (ibid., Pp. $38 \mathrm{ff}$ ). The temples are considered a type of museum for the ancient Iraqi, although he does not know the concept of the museum in its modern concept due to the presence of these temples of gifts and offerings and alabaster vessels of various shapes and sizes and types include jars and cups and dishes and a group of cylindrical seals and some other pieces of small copper sculptures of oxen and copper plates It was engraved with drawings of lions and crows, some of which depicted an eagle spreading its wings. They were found in the Or Temple (ibid., Pp. 218-219). This situation did not differ from the ancient Egyptian temples, which are somewhat similar to museums (Mohamed, 2002, p. 23). The ancient Iraqi did not seek to collect the collectibles and gifts of sculptures, drawings, and manuscripts in one specific place to present them to people to taste their art and beauty as modern museums, but were displayed in the squares, temples, gardens, palaces, and the best example of this is the hanging gardens, zigguras, temples, and the same case of the ancient Egyptian, Greek, and Roman. It can be said that the beginning of the idea of museums in cities originated from the Greeks, and the viewer of its temples finds many statues and artistic monuments that were developed in beautiful styles that are consistent with the place to decorate it only. It also contained stores for preserving precious treasures, ornaments, statues of kings and greats, important figures, drawings and 
engravings that embody their daily and religious works. However, the idea of museums in the Roman era embodied in a broader way and clarified to Milan the Emperors of the Romans to collect and acquire artistic treasures that express their strength, courage and numerous conquests in a vivid expression and the necessity of presenting them to the people to educate them and raise their intellectual level in order to appreciate the beauty and artistic taste, therefore the Roman leader (Agrippa) opened his palaces to the masses saying The best of art is to be at the disposal of the masses (ibid., P. 26).

As for the Islamic ages, when luxury and prosperity increased during the Umayyad and Abbasid era, the caliphs and princes increased their interest in acquiring and collecting antiques and various valuables in their palaces. In the Middle Ages, people would not care about the remains of the past, and the places of worship themselves became museums, as they express eternity and nothing else. Whereas the Renaissance turned to the study of man and his accomplishments, it was possible to estimate artistic works of their own, not as reflections of sacred science, then the development was in the great groups of the Renaissance. As the Medici family, one of Florence's most famous families, this family was known for its patronage of art and artists. The museum did not appear as a separate building until the end of the seventeenth century $\mathrm{AD}$, following the development of two types of sub-buildings (Al-Khazna and Al-Hall) (Awad, 1994, p. 4). While Egypt occupied a prominent place and a pioneering role in building and constructing museums, it is considered the first Arab country that took care of it by order of its ruler, Muhammad Ali Pasha, in 1835 AD to establish an interest and museum for antiquities (Muhammad, op. cit,). There are several types of museums. 1- Art museums. 2- Historical museums. 3- Scientific museums 4- Natural history museums and research centers. 5- Natural museums. 6Children's museums. 7- Community and ethnic museums. 8- Specialized museums. 9- Public museums. 10- Encyclopedic museums.

\section{CONCEPT OF NATURAL HISTORY MUSEUM AND RESEARCH CENTERS}

Research centers are defined as scientific institutions that aim to link educational and educational institutions with societies inside and outside the country by providing advisory services and adopting research that contributes to development and linking community bonds and exchange experiences and cooperation between local and international scientific bodies and publishing and documenting scientific research in addition to that they carry out the task of diagnosing and classifying The various models achieve this goals of scientific research and publish their results for the purpose of taking them to serve society through scientific seminars and conferences. Also, they are essential sources for researchers of various paths and scientific levels. These centers are considered the main catalyst in the development of society and its prospects for the future prospects of the development of human society, starting from being considered an indicator of civilizational and cultural achievements, and a title of rapid progress and one of its indicators in development and drawing the right policies.

The countries of the world have been interested in establishing museums of natural history in the modern era as they relate to the study of organisms and all living organisms, including plants and animals in their environments, using observation methods, and despite the differences between those countries in terms of geographical dimension, for example the Natural History Museum in London and Washington, the means and methods The display of the displayed models is somewhat the same. Natural history includes scientific research and is not limited to it. It forms an umbrella covering many branches and scientific disciplines related to living organisms. Most definitions make natural history intertwined with other sciences such as botany, zoology, biology, and biogeography, as well as fossils, ecology, and biochemistry. Natural history studies mainly plants and animals within their environment, concerned with levels of organism and its forms from the individual organism to the entire ecosystem and attempts to distinguish between species and the history and development of life as well as the availability of species and interrelations between species (Ministry of Knowledge, 1950, p. 8 and beyond). 


\section{EXHIBITS HALL OF THE IRAQI NATURAL HISTORY RESEARCH CENTER AND MUSEUM}

The Iraqi Natural History Research Center and Museum was established on May 2, 1946, in the AlAwadiyah Ministerial District in a small house that has evolved over the past decades (ibid., P. 11). It is currently located in the Bab Al-Muadham area in the colleges complex. It is unquestionably one of the civilizational landmarks in Iraq and a platform for science students in all academic stages. The museum daily hosts dozens of colleges and schools students with different walks of life and their stages of study in addition to that from graduate students in Iraqi universities and the diagnosis of their models The fact that the museum is the main Iraqi reference in diagnosing models related to its natural history and receiving researchers from various Iraqi ministries.

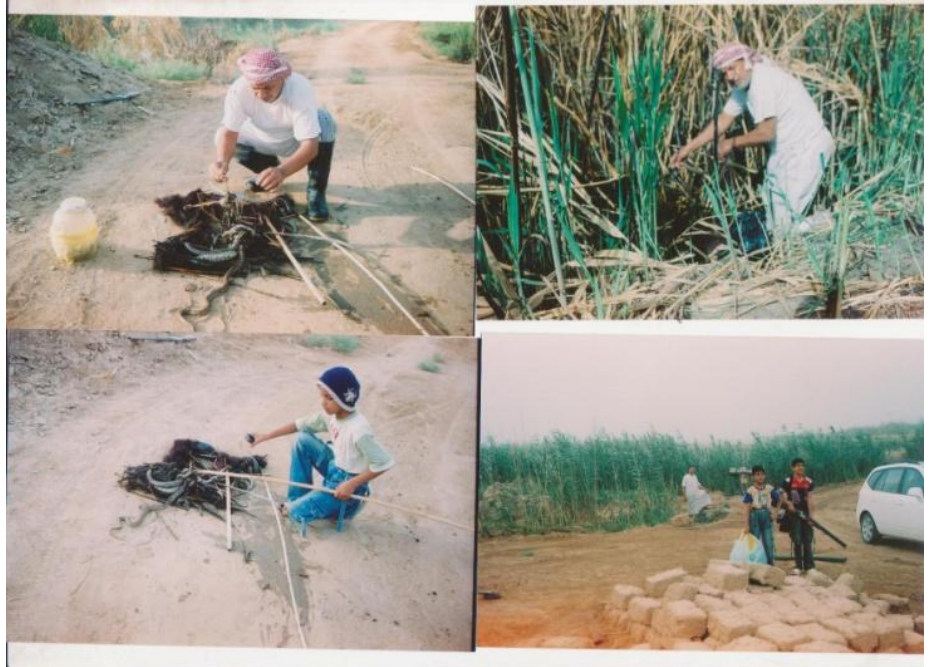

(Figure 4) The process of collecting types of snakes and wild birds models by the researcher and his children (Muhammad and Ali) in the Tarmiyah swamps north of Baghdad.

Also, because the museum owns a hall to display local and international models, in addition to that from other neighboring regions, this hall is the largest and oldest in the level of Iraq from a building distinguished in terms of engineering and aesthetic.

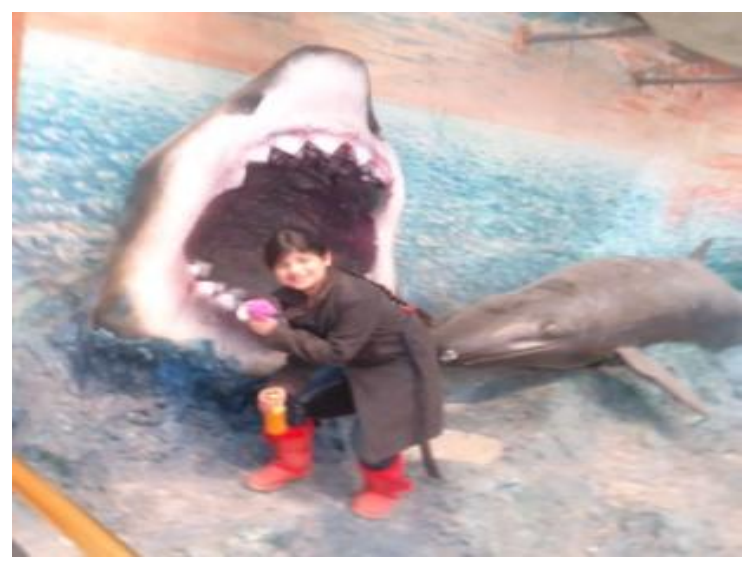

Figure (5) anthropomorphic shark head (consisting of materials: cement + building gypsum + cork + metal wire) The size of the fish head is observed compared to the size of the child (Konooz) of the researcher's daughter.

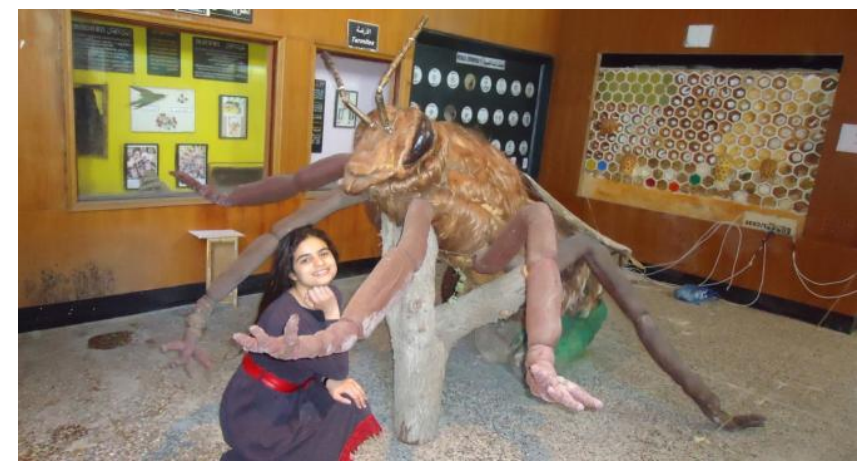

Figure (6) large bee anthropomorphic made of different materials (iron + cork + metal wire + goat animal hair + plastic + fabric). The size of the bee is observed in comparison with the size of the researcher's daughter (Huda).

The hall contains a group of different models, some of which date back to a century, in addition to anecdotes through gifts and intimate scientific relations between Arab, Islamic and international research centers and institutions, starting from the foundation and to this day, as well as collecting models by hunting (Figure 4). And field trips over the years and days that are conducted by researchers of the specialized scientific center for the various regions of Iraq, the main supporter and the aortic artery in supplying the exhibition hall with models, many of which are the product of those field trips. These models in the exhibit hall offer a service to the various slides and scientific levels that go to this valuable edifice. 
The Center has witnessed important transformations at the media and administrative levels by creating new models and models for stuffed animals and groups of insects and plants that represent the history of normal life in Iraq in particular. The technical unit, under the direction of the director of the center and under the supervision of the head of the technical unit (researcher), entered the first hypothetical skeleton of one of the dinosaur classes in the center's exhibition hall of industrial raw materials that are not affected by climatic conditions.

This achievement is an advanced step in the history of Iraqi museums in the modern era. And another anthropomorphic animal mammoth. The organizers of this project emphasized that this model simulates what is found in international museums. And a model for the head of the shark (Figure 5), and the work of another model for the bee insect (Figure 6). The center as a culturally ancient symbol of Iraq historically.

Its journey did not stop to these disparate boundaries and standards, but rather won a prominent place in the Research Center and the Museum of Iraqi Natural History, as it was allocated special tanks in the museum's exhibition hall and tracks its history from the dawn of the civilization of Iraq to the present day. There are tanks for its stages of growth and others for its most important products and another tank for its place in the ancient arts of Iraq on the number of clay and cylindrical seals in addition to the great murals that immortalize the first leaders of Iraq and their relationship to the palm. To that, a three-dimensional work of the palm tree is created as part of the Iraqi heritage in front of these reservoirs. Below are some of the artistic achievements of the palm elements in the museum exhibition hall and highlighting its heritage aesthetics:

(Fig. 7) represents a set of scenes and landscapes of the palm tree, some of its products and historical stages have been embodied art.

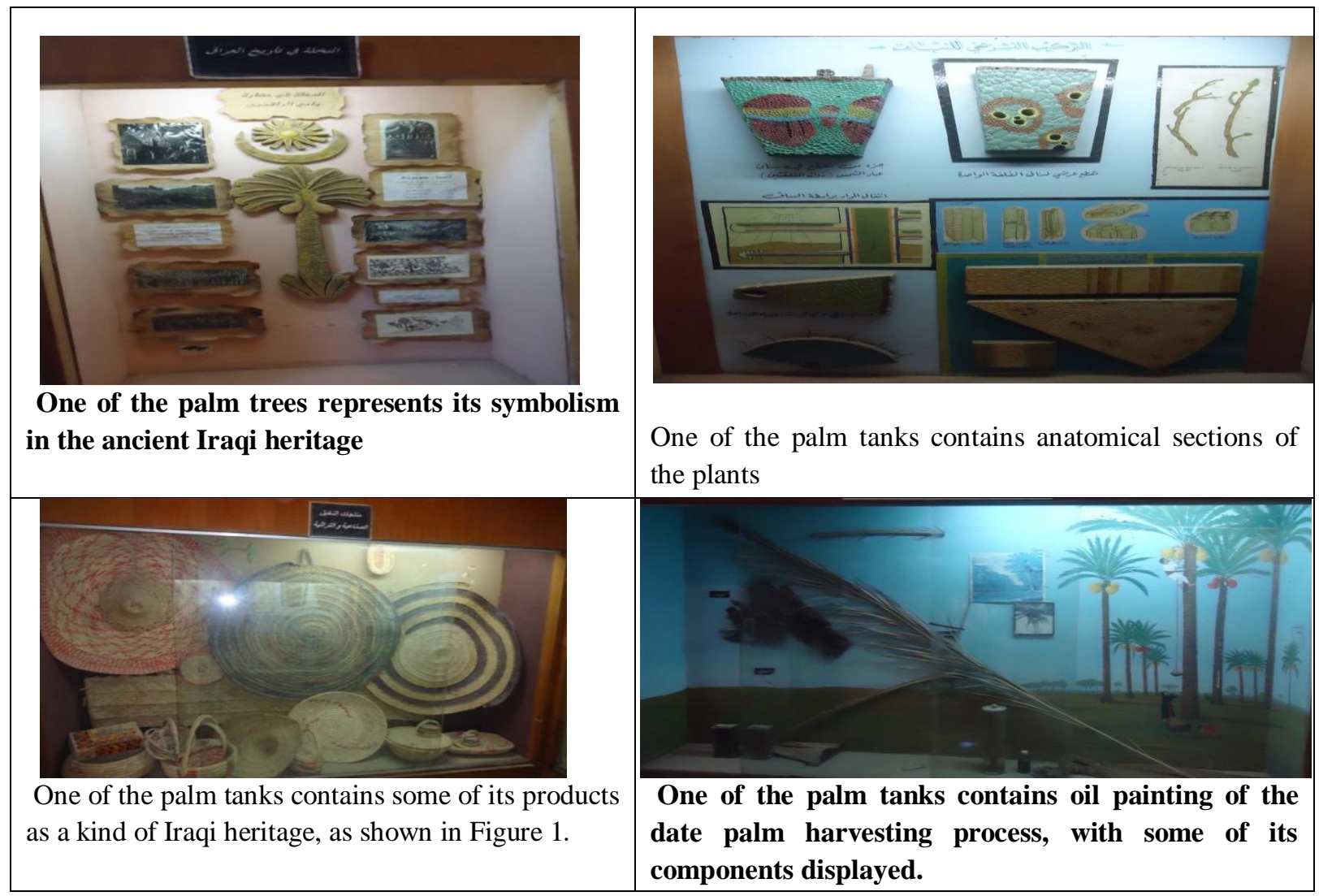




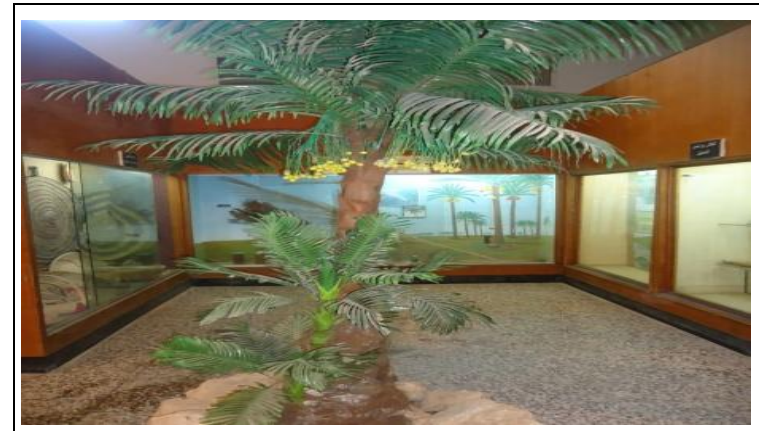

A palm tree with its plastic seedlings and some natural materials that decorate it (in front of the palm tanks in the hall).

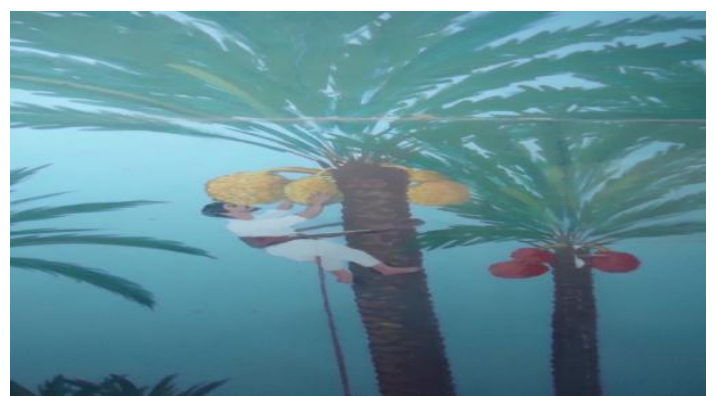

the palm tanks contains an oil painting of the date-harvesting process and some parts of the palm tree and its products.

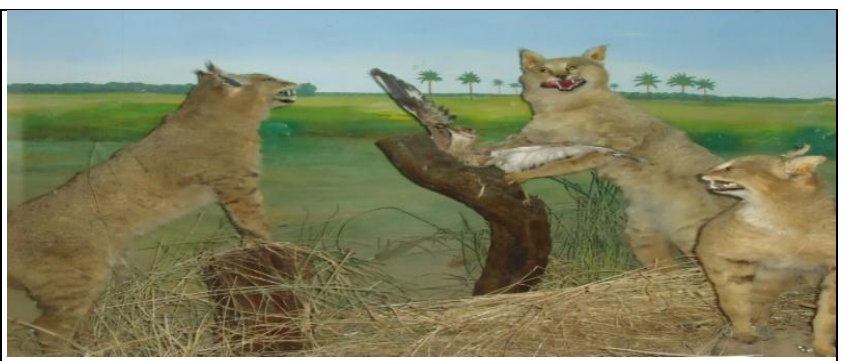

Palm oil painting behind the stuffed models (wild cats) as part of an Iraqi peasant environment.

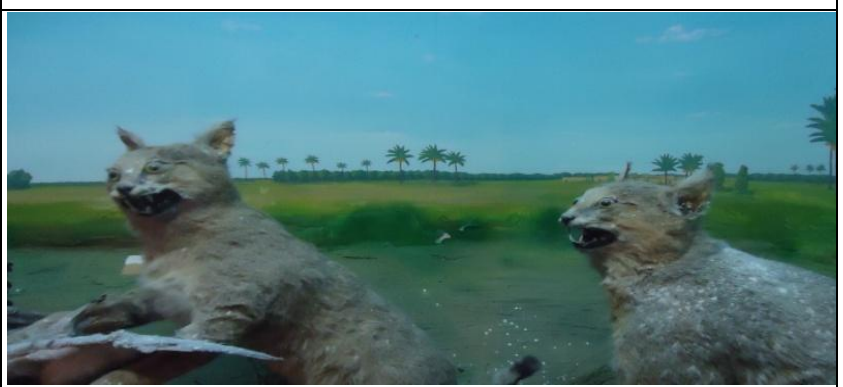

One of the palm tanks contains an oil painting of the date-harvesting process and some parts of the palm tree and its products, a kind of frequent local heritage.

\section{CONCLUSION}

After this serious trip to the topic of the role of the Arab heritage in enhancing beauty, the Museum of Iraqi Natural History and the modernization of its display means to increase the popularity of visitors, researchers hope their success in providing sufficient and transparent answers to the questions of the study problem in which it was presented, and then achieving the desired goals and producing important results, and to verify It can review the answers to those questions:

1) It appears that heritage is in the language: it is all that a man succeeds to his heirs, i.e. his children and his family after him, and he is inherited after him by virtue of the statute of limitations and transfer.
2) It appeared that there are types of heritage: material, intellectual and social. And the human heritage that the first person left to the other as frequently as the ancient Iraqi, pharaonic, Greek, Roman and Islamic heritage. The human cultural heritage is the most comprehensive and broadest.

3) It appeared that there were several Iraqi artists who were inspired by their ancient and Islamic Iraqi heritage and were able to employ their heritage in most of their artworks, most notably the great artist Ayath Abdul Rahman Al-Douri (Figure 2) and the pioneering artist Salam Jabbar Jiyad (Figure 3).

4) It appeared that the research centers are scientific institutions that aim to link educational and educational institutions with societies inside and outside the country and adopt research that contributes to development 
and publish and document and diagnose and classify various models, including birds, fish, snakes and insects (Figure 4).

5) The museums are permanent educational, cultural, and educational institutions that serve the community by collecting, preserving, displaying and maintaining civilizational, historical, human and natural heritage, as they are the body that collects and maintains the heritage of humanity and maintains it and displays it in interesting and interesting ways.

6) The figures are masterpieces, molded artworks, or formed from one rigid material or several materials, in the form and form of other material such as human figures, different animals, insects, and reptiles (Figures: 5,6). The views are divided into two parts: (fixed and auxiliary displays).

7) Vocabulary of the Arab heritage such as the palm tree and its products of handicrafts inherited in the tanks of the exhibition hall of the Iraqi Natural History Museum were introduced as a kind of heritage beauty that was prevalent in the ancient Iraq civilization and the Arab Islamic civilization (Figure 7).

8) There are strong relationships between research centers and museums, and between educational and educational institutions.

9) These relationships helped to communicate scientific and educational concepts in visual and illustrative ways that reduce the idea to learners on their age and professional differences.

\section{RECOMMENDATIONS AND PROPOSALS:}

In light of the results of this study, it is possible to include some recommendations and proposals through which the researcher hopes to be useful.

\section{First: Recommendations:}

Among the recommendations considered important:

A. That the directors of educational institutions acquaint themselves with this study, in order to find out some educational methods developed by the research centers and museums.

B. To hold training courses for teachers, through which they are acquainted with research and studies that deal with the relationship between the role of the media of the Iraqi Natural History Museum and the modernization of its display methods, and are trained in the production of educational methods and their uses.

C. That the programs of preparing and training teachers include various courses on museum educational means from theoretical and practical aspects, with a focus on modern methods of presentation using advanced techniques.

D. It should be emphasized in the educational curricula on the importance of using museum educational aids, as an essential part of the curriculum and the entire educational process.

E. Conducting more research that deals with ethical concepts and aesthetic standards in the arts of human civilizations and interest in creating plastic works embodying the most important models and vocabulary that represents a part of the local heritage such as fountains and marshes and waterfalls with a design vision that deepens the sense of belonging to the homeland and taking into account the mental needs of the citizen with regard to what the place offers of the service And an aesthetic value that would perpetuate that affiliation and arouse the hidden feeling of the individual towards his homeland.

\section{Second: The proposals:}

The researcher suggests:

a. That the vast potential enjoyed by computers be used to consolidate and develop relations between research centers and museums and between educational and educational institutions, to be in the hands of learners, researchers and those interested in educational and educational heritage that will endow the world educational heritage with high value and great service for future generations.

b. That this study be addressed in scientific studies, master's or doctorate, to capture the prospects of this topic in deeper and broader ways, so that all educational means between research and museum centers and 
between educational and educational institutions are investigated.

c. Conducting a comprehensive scientific study on the educational methods used by the research centers and museums and what additions they have provided in the light of modern and advanced data for contemporary technology.

d. Establishing research and museum centers according to the following:

a. Site selection.

b. The area.

c. The number of associates, researchers and department managers.

d. The number of building floors.

e. The spaces fit with the models presented directly.

f. Its comprehensiveness in terms of diversity and distribution of models locally and globally.

g. The flexibility of visitor traffic.

h. It provides restaurants and movie theaters (3D).

i. Various training and entertainment means.

j. Selling and displaying small scale models for the most prominent displayed models, books and pictures.

\section{Inference}

k. Entry should be free in order to attract visitors.

1. The flexibility of the building to adapt to the tremendous development in future displays and discoveries.

m. Display live examples such as bees, butterflies, insects, and aquatic organisms.

- Museums and research centers achieve an aesthetic vision, which depends on the visual responses formed in the form of visual work done and keeps the heritage from being lost.

- The museums aim to achieve a visual vision, which works from the extent of the connection with the invisible reality represented by the life that ancient people lived in ancient times and the various legacies it left today.

- The research centers and museums were able to attract the public to them, especially those affiliated with educational institutions, to provide the learners with a variety of illustrative means, and thus achieve communication with the global human heritage.

\section{SOURCES}

1. Abbas, Ihsan (1992). Trends of Contemporary Arab Poetry, Dar Al-Shorouk, Amman, $2^{\text {nd }}$ Edition.

2. Al-Khaffaf, Abd Ali and another (1420 AH / 2000 CE). Studies in the Arab Islamic Geographical Heritage, AlKindy House for Publishing and Distribution, Irbid, The Hashemite Kingdom of Jordan.

3. Al-Nuaimi, Ahmed Ismail (2005). Myth in Pre-Islamic Arabic Poetry (University Thesis Series), Dar al-Shu un Public Cultural Affairs, Baghdad, $1^{\text {st }}$ edition.

4. Al-Omari, Akram (1405 AH). Heritage and Contemporary, Doha, $1^{\text {st }}$ edition.

5. Al-Sharafi, Abdul Majeed (2008). Islam between Message and History, Library of New Thought, Dar Al-Tale'ah for Printing and Publishing, Beirut, Lebanon, $2^{\text {nd }}$ edition.

6. Armstrong, Karen (1429 AH / 2008 CE). History of legend, see: Wajih Kanso, Arab Science House Publishers, Beirut - Lebanon, $1^{\text {st }}$ Edition, margin.

7. Awad, Amal Abdel-Khalek Mahmoud (1994). Basics of Interior Design for Applied Museums in the Arab Republic of Egypt, Unpublished Master Thesis, Faculty of Applied Arts, Department of Interior Design, Helwan University, Egypt.

8. Badawi, Ahmed Zaki (1986 AD). Lexicon of Social Sciences, Lebanon Library, Beirut.

9. Baqer, Taha (1400 AH / $1980 \mathrm{AD}$ ). Gilgamesh saga and other stories, epics and the flood, publications of the Ministry of Press and Information - Iraq Republic, Series of Studies (202), Freedom House for Printing, Baghdad. 
10. Cering, Philip (1992 AD). Symbols in Art - Religions - Life, Trans.: Abdel Hadi Abbas, Damascus House, $1^{\text {st }}$ Edition.

11. Diab, Abdul Majeed (1993 AD). Achieving the Arab heritage, methodology and development, Dar Al-Maaref, $2^{\text {nd }}$ edition.

12. Durant, W.L. (2001). The Story of Civilization, The Egyptian General Authority (Book 6), The Family Library Volume One, Cairo.

13. Gold, Peter (1996). Time, space and humankind, International Journal of Social Sciences, UNESCO, No. 150.

14. Gospel of Matthew, chapter 28.

15. Ibn Khaldoun, Abd al-Rahman (n.d). Introduction by Ibn Khaldoun, Cairo, Dar Al-Shaab.

16. Ibn Manzur, (1990 AD). Lisan Al-Arab, Dar Al-Fikr, Beirut.

17. Ismail, Ahmed Ali (1993). Studies in the geography of cities, Cairo, the House of Culture for publication and distribution.

18. Jabbour, Abdel-Nour (1979). Literary Dictionary (the term Arab-Human Heritage): Beirut.

19. Ministry of Education (1950). House of High Teachers, General Report for the years 1946-1949 (History of establishment, management and exhibits of the museum), Iraqi Natural History Museum Bulletin No. 1, Government Press, Baghdad.

20. Mola, Ali (1998). The Arabic Encyclopedia, Volume 1 (A - Arians), Syrian Arab Republic, Damascus, $1^{\text {st }}$ edition, 1998 AD.

21. Muhammad Ali, Muhammad Abd al-Latif (1977). The history of ancient Iraq until the third millennium BC. M. , Alexandria Library

22. Muhammad, Refaat Musa (2002). Introduction to the art of museums, Arab Republic of Egypt, the Egyptian Lebanese House, Cairo, $1^{\text {st }}$ Edition.

23. Qadous, Ezzat Zaki Hamid (2005). Palaeontology and museum art, Arab Republic of Egypt, Dar Al-Maarif AlJami'a, Alexandria.

24. The Bible (1991). (It is the books of the Old and New Testaments, translated from the original languages), Call of Hope, Stuttgart, Germany, translation: VanDyke and the Gardener revised, 1991 AD, Luke's Gospel, chapter 24.

25. Zayed, Ali Ashry (1978). Summoning the heritage figures in contemporary Arab poetry, the General Company for Publishing and Distribution, Tripoli, $1^{\text {st }}$ Edition . 